\title{
The Making of an Egyptian Social Media Influencer
}

\author{
Hanan Ezzat, University of Rovira i Virgili, Spain
}

\begin{abstract}
This qualitative study, set against the backdrop of Egypt, examines how social media influencers construct their online identity and build their online persona. Social media, which have been primarily developed in the West, have infiltrated the Egyptian society; they have opened doors to different forms of personae and content such as social media influencers. In Egypt their numbers have increased, and they have become an important part of the social media scene. They aim to build their audiences and fan bases with the ultimate objective of monetising their presence. This study focuses on nine Egyptian social media influencers, through employing in-depth interviews, and seeks to explore how they construct their online identity and how they build their distinct personae. The analysis revealed that they build a distinct online person for themselves to impress their audiences and fans. Moreover, they perform authentically; they seek to be perceived as authentic and to display this authenticity they undertake a number of processes.
\end{abstract}

Key words: youth, influencers, Egypt, online persona, authenticity.

\section{Contextualising Egyptian social media influencers}

This study is set against the backdrop of Egypt. Situated in northern Africa it deviates more towards the Arab World also known as the Middle East. The Egyptian society is a traditional, patriarchal and keenly religious society (Gadallah, Roushdy, \& Sieverding, 2017; Roushdy \& Sieverding, 2015; Therborn, 2004). It is characterised by oral based traditions (Ayish \& Alnajjar, 2019); however, this is shifting with the advent of social media; new generations access alternative sources of information and form their opinions far from their parents (Sabbagh, Mourad, Kabbara, Shehadi, \& Samman, 2012). The Egyptian society is characterised by what the United Nations refers to as a youth bulge, which is described as when the relative number of children decreases, populations experience a growth in youth as a share of the total population (United Nations, 2018). In Egypt the percentage of youth in the age bracket 10-24 is one third of a society of 100 million people (UNFPA Egypt, 2020). These young people are also the heaviest users of social media in terms of time spent and content consumed (Sabbagh et al., 2012). 
The core group in this study are social media influencers (hereafter influencers). Influencers are ordinary individuals who have taken to the internet and social media to develop and share content while monetising their existence (Abidin, 2015). Their primary objective is to grow their audiences and fanbases as more fans equates more income for them. Initially influencers started off as informed bloggers and through that they reached their audiences who considered them as experts and authorities (Friedrichsen \& Mühl-Benninghaus, 2013). There are a number of synonyms for the word 'influencers' such as 'creators' 'microcelebrities' (Senft, 2008) and on Instagram, 'Instagrammers' and 'Instafamous'. With the increase in the number of influencers it was natural for research to focus on them and examine them more closely, whether their rise or their presence and influence or the tactics they use.

The following covers an overview of trends in studies around influencers. The first trend in the studies pertains to studies about the role influencers have in marketing and brand endorsement. These studies assume a role for influencers in endorsing brands and consequently influencing purchases given that people adopt behaviours and opinions from another person or group that conforms with their self- definition and aspirational images (De Veirman, Cauberghe, \& Hudders, 2017; Uzunoğlu \& Misci Kip, 2014). This group represents a major group of studies as this is a role influencers are typically associated with (Chapple \& Cownie, 2017; Colliander \& Dahlén, 2011; Lee \& Watkins, 2016). The second trend in the studies focuses on specific named influencers and looks at their communities and examines this more closely. To a large extent these studies document influencers' activities and practices to create their online personas (Berryman \& Kavka, 2017; Cocker \& Cronin, 2017; García-Rapp, 2016; Hurley, 2019; Jerslev, 2016; Jorge, Marôpo, \& Nunes, 2018; Marôpo, Jorge, \& Tomaz, 2020; Martínez $\&$ Olsson, 2019). The third trend the in studies examines the relationship between influencers and their audiences (Aran-Ramspott, Fedele, \& Tarragó, 2018; Pérez-Torres, Pastor-Ruiz, \& Abarrou-Ben-Boubaker, 2018; Westenberg, 2016). The fourth trend in studies looks at specific genres of content developed by influencers such as beauty and lifestyle vlogging (Abidin \& Ots, 2015) and transgender vlogging (Raun, 2018). The overview of influencer research shows the diversity of research foci. This study falls under the second trend of studies.

The Arab Media Outlook (2016-2018): Youth.Content.Digital media report, highlights that influencers in the Arab world have the potential to be a source of local culture and develop their influence to leverage far greater social benefit beyond their current marcomms revenue streams. It states five main reasons for their growth in the Arab world: youth demographics of the region, technology adoption, social media, emergence of short content formats and convenience of consumption. Furthermore, the report explains that possibly the single biggest driver of influencers is the strong youth skews the region has with a large percentage of youth in all countries as opposed to the percentage of youth (Dubai, 2018); this is true of Egypt and its youth bulge. 


\section{Reframing influencers in the Egyptian context}

The importance of influencers in this study stems from the importance of their audience and fans, who are primarily youth. Egyptian youth have demonstrated to the world that they are agents of change and were key in the Egyptian 2011 revolution (United Nations Development Programme, 2016). These young people spend a high percentage of their time on social media following influencers as well as other social media personalities such as celebrities (PressRoom, 2015); therefore understanding influencers better contributes to understanding what forms the outlook, thoughts and ideas of Egyptian youth. This is important in a country like Egypt where there is a glaring absence of youth role models (Jung, Petersen, \& Sparre, 2014).

Traditionally influencers have been defined in literature as third party endorsers (De Veirman et al., 2017; Freberg, Graham, McGaughey, \& Freberg, 2011; Uzunoğlu \& Misci Kip, 2014). However, beyond the marketing and brand endorsement role of influencers, they play a more significant role with their audiences. A role which represents some sort of impact, influence and effect (Ayish \& Alnajjar, 2019).

It's worth noting that the majority of the studies in this part of the world and specifically in Egypt, in the last decade or so, have focused on the mobilisation role social media play due to the monumental event of the Egyptian revolution. Researchers have been able to find different angles to this same topic hailing the role social media played or downplaying it and in some cases presenting a controversial view (Attia, Aziz, Friedman, \& Elhusseiny, 2011; Bhuiyan, 2011; Herrera, 2012; Khamis, S., \& Vaughn, 2011; Khamis, Gold, \& Vaughn, 2012; Morozov, 2011; Olorunnisola \& Martin, 2013). Therefore, this study represents a shift from this direction, to look into the other roles social media can play, in the case of this study, through influencers. It will fill a gap in research and contribute originally to knowledge about influencers.

\section{Study goal}

This study aims at exploring how Egyptian influencers construct their online identity and build their online persona, i.e. what goes into the making of an Egyptian influencer. The research questions pertaining to the study goal include the following: How do influencers present themselves online? and how do they build their online persona?

\section{Theoretical influences and concepts}

The study will depend on the work of two key scholars in self-presentation, namely Goffman (1959) and Leary (1996). Goffman, as a seminal scholar in self-presentation, developed an approach based on dramaturgy to explain how individuals present themselves to others and what they employ in the course of this process. Within his dramaturgical approach he explains 
that when an individual appears in front of others, he/she tries to control the impression they give to others through performing. The individual in this case will observe social rules and conventions (Bullingham \& Vasconcelos, 2013; Goffman, 1959; Jenkins, 2008). Others which represent the audience and are a key group within the dramaturgical approach, in their turn, seek to gather information about the individual from their direct and indirect cues. Goffman clarifies that within the process of trying to give a specific impression to others, there are other unintentional impressions which can reach the audience. In spite of Goffman's approach being developed pre the digital era, it resonates today as proven by numerous studies (Birnbaum, 2008; Bullingham \& Vasconcelos, 2013; Burns, 1992; Nesvadba, 2017; Serpa \& Ferreira, 2018; Smith, 2006).

Leary (1996), another seminal scholar on self-presentation developed a number of tactics for self-presentation. Some of his tactics include self-descriptions, attitude statements, public attributions, remembering and forgetting, nonverbal behavior, social associations, conformity and compliance, the physical environment and other tactics.

The study will also draw on the theoretical concept of displays of authenticity which may provide an additional dimension to the findings. Authenticity as a construct and concept has many definitions depending on which tradition looks at it. Authenticity typically refers to what is genuine and true (Beverland, Farrelly, \& Quester, 2010). As a symbolic construct it has a cultural value in how individuals understand themselves and how they make decisions about how to live life (Banet-Weiser, 2012). Taking this into mind authenticity acts as a moral compass. Enli (2015) emphasises that authenticity is a communicative and negotiation process that takes place between the main players in communication especially in terms of trustworthiness, originality and spontaneity. It's worth noting that the majority of studies which have looked at authenticity link it primarily to celebrities (Ellcessor, 2012; Meyers, 2009).

\section{Methodology}

To achieve the study goal and address the research questions, a qualitative approach was deemed most appropriate, given that qualitative methodology is fluid, flexible, exploratory and context sensitive. The Egyptian society is not accustomed to research per se and people are quite skeptical to give out information, therefore contextual sensitivity is key to this study. The other factor which determined the methodology was the intricate nature of online identity (Bullingham \& Vasconcelos, 2013); this nature renders the collection of rich data such as opinions and observations of users and what they think. Accordingly, the author interviewed nine Egyptian influencers to collect rich data for the study.

The author set a number of inclusion criteria: all Egyptian with a significant fanbase of subscribers on YouTube and/or followers on Facebook and Instagram. Influencers were categorised into two categories based on their fanbase numbers across social media (Ruiz- 
Gomez, 2019). The first category was named 'tier 1' and these were influencers with a fan base of one million or more and 'tier 2' and these were influencers with a fan base of more than $100 \mathrm{~K}$ and less than one million. Tier 1 influencers are typically known as mega-influencers and tier 2 as macro-influencers. This study excludes micro-influencers (less than 100K).

Recruiting influencers proved to be a challenge and a major hurdle especially tier 1 influencers. To identify potential influencers to participate in the study, the author used social media tools such as the 'trending tab' on YouTube (YouTube, 2020), in addition to websites which ranked the highest viewed influencers in Egypt. Initially the author drew up a list of 15 influencers to target. Using purposeful non-probability sampling (Given, 2008), the author started to reach out to influencers using their business emails. They all clearly displayed those emails on their channels/pages/accounts, in addition to the availability of sending messages on Facebook messenger or Instagram direct messages. The initial response was no response; it seems that for influencers time is money Therefore, it took quite some time to start to get a response from influencers. Eventually, the author targeted 40 influencers: 17 of which were tier 1 influencers and the remainder tier 2 influencers; 22 males and 18 female influencers. The response rate was $27 \%$ as initially 11 influencers agreed. However, out of the 11 who agreed, 2 declined later. Two of the influencers at the time of the study were tier 1 influencers and the remaining ones were tier 2 influencers.

The first step was to get a contact phone to be able to explain clearly to them what the study was about and secure a time slot for the interview. All influencers who agreed to an interview did not entertain the idea of meeting face-to-face; they spoke about their time limits and tight schedules.Therefore, all nine influencers opted for a phone interview at the time of their choice. The nine influencers who were interviewed were Alaa Ghabour (YouTube Channel), Ahmed Barshoumy (Facebook page), Hoda Rashad (YouTube Channels: Banat 7awa and Chefista), Lamia AlBardici (YouTube Channel), Mohamad AbdelKader-AlBashmozee (Facebook page), Nada Fouda (YouTube Channel: Dudy Lifestyle), Nader Ahmed (YouTube Channel), Nader ElKomely (YouTube Channel) and Samar Ahmed (YouTube Channel).

The nine influencers had different online personas, some narrated their lifestyle, others reviewed products and shared their experiences around using these products while some used comedy to represent their persona. Alaa Ghabour (female) narrates her lifestyle and advocates for fitness and wellness. Ahmed El Barshoumy (male) has the distinct persona of a male with a beard imitating young veiled girls in everyday situations such as dating, shopping and friendships. Hoda Rashad (female) shares her experiences with natural products and her skills as a cook. Lamia AlBardici (female) encourages women to take care of themselves through fashion and beauty. Mohamed AbdelKader (male) embodies a young traditional Egyptian who tries to advocate going back to traditions and a conservative lifestyle. Nada Fouda (female) focuses on DIY activities as well as self-development one, her key message is women empowerment. Nader Ahmed (male) depends on acting out comedy sketches depicting young 
people in daily situations such as exams, outings and dealing with their parents. Nader ElKomely (male) depends on acting out relationships between boys and girls showing modern Egypt and Samer Ahmed (female) shares her DIY skills and how to become beautiful and fashionable on a budget.

Prior to the interviews, the author followed heavily the channels of the influencers, almost becoming a fan, watching a number of videos for each influencer and following them on their various social media platforms. This helped immensely during the interviews to refer to topics they covered or a specific video or post which in turn created rapport and built trust between the author and them.

The author developed an in-depth interview guide outlining the key topics that needed to be covered in the interview, allowing flexibility which is the beauty of an interview. The interviews were carried out over the course of one month in the period 1 to 28 February 2019. The author found that by the seventh interview not much new data was being generated; however, additional interviews were conducted to ensure that the saturation point had been reached. All interviews were audio recorded after gaining consent from the influencers. After the interviews, the author reached out to the influencers to thank them and two of the influencers sent additional information about their audience. Following the interviews and write-up of transcripts, the author coded the data. The coding and analysis of the interviews generated a number of themes. The two themes which emerged included social media appropriation and displays of authenticity. Under these two themes came the subcategories of motives, platforms, aspirations, content, going live, photographs and maintaining a distance.

\section{Key findings}

In line with the themes, key findings were split under two broad headings: social media appropriation and displays of authenticity.

\section{Social media appropriation}

Influencers used social media to their advantage, they appropriated it through motives, platforms, aspirations. All of the influencers had different motives for using social media, however, what they had in common was using social media to grow their audience numbers and fan bases; this was key and very important to them. An interesting perspective mentioned by all of them was about how they started randomly without a clear objective in mind and then when they were well received by audiences they decided to continue and take this on as a profession. Influencer Samar Ahmed stated: "I started that as a trial and there was nothing to lose and things worked out. I found people liking my channel and liking me". Influencer Nader Ahmed echoed this: "The start was a bit random, over the years, I learnt a number of things that helped me produce a video". 
Influencers explained that as time went by, they developed clear messages and missions for themselves. This could be considered the start of creating their online persona. Influencer Alaa Ghabour who narrates her lifestyle stated:

My main message is that every person should become a better person and this is the main thing I will continue to advocate for. Anything that I do is to make the viewer change his mind about a certain thing to become a better person.

Influencer Ahmed El Barshoumy stated: "My objective is to entertain people. I want them to see my videos and laugh, there isn't a specific message I just want people to laugh".

In order to grow their fan bases, influencers used strong words to describe themselves online. In that they employed Leary's self-presentation tactic of self-description. The words they used could really pull in specific audiences to them, for example: 'Egyptian YouTuber' 'Trust in God' (influencer Samar Ahmed), 'Fashion, Beauty \& Lifestyle' 'Civil Engineer' (influencer Lamia Albardici), 'Winner of YT Next up 2016' 'Vegan' 'Women empowerment' 'Mommy of 2' (influencer Nada Fouda), 'Engineer' 'Actor' 'YouTuber' 'Influencer' (influencer Nader ElKomely).

One of the surprising findings was that financial gain and benefits were not mentioned as one of the motives for influencers. This is typically what defines influencers and in the case of influencers in this study they all monetised their presence and developed sponsored content; however, they did not speak about it. Influencer Nada Fouda stated:

My objective is not financial. If I had a financial objective, I wouldn't have started the channel at all (laughs), because profits from the channel take at least two years or even three to materialize, and the income is not that high compared to the hard work that goes into it.

On the topic of platforms, influencers all started on a specific platform and then branched out from there to other social media platforms. Those who started on Facebook for example, had a large number of followers there, while those who started on YouTube had large numbers of subscribers there. They used additional platforms to widen their fan bases because different platforms have different strengths. For example, Instagram is more photo and video based than the other platforms. Influencer Nader Ahmed explained: "Other social media channels help me distribute the video ... so they all complement each other and help me reach the largest number of people who follow me with whatever new content I am presenting”.

Moving onto aspirations, influencers had a wide range of aspirations, some of which were related to their online presence and others beyond social media. The male influencers especially 
all had ambitions to move into mainstream media or cinema. They expected that their presence on social media will help them become known and sought after by the media. For example, Influencer Ahmed El Barshoumy stated, "having my own program", while Influencer Nader Ahmed stated, "to become a TV presenter". Similar to their objectives, none of the influencers spoke about money and financial gain as an aspiration. This is in line with findings by previous studies Audrezet et al. (2018) and Moulard et al. (2015; 2016; 2014), which found that influencers are driven by their inner desires and passions and not by commercial goals.

\section{Displays of authenticity}

The second set of findings are around the key process influencers use to build their online persona which is displays of authenticity. Overall, influencers spoke about wanting to create a specific impression on their audiences and fans, in that they were in line with Goffman's (1959) dramaturgical approach which indicates that individuals, in the presence of others, seek to create a specific impression on others. However, for influencers in this study they aimed to create a specific impression and at the same time give 'an authentic performance'. In this they were displaying authenticity. When discussing this specifically in the interviews with influencers, they interpreted authenticity as how much deviation there is between their personality in real life and the personality they project on screen. Marwick (2005) similarly identifies authenticity in how close are the online and offline. In general, there was a collective sentiment that there was no deviation or very little deviation from the real personality on screen. Influencer Hoda Rashad stated: "What shows is very close to reality". Influencer Lamia Albardici echoed this: "It's exactly the same because I believe that to fake it or to act in a certain way is very difficult; to pretend is very difficult it's also difficult to pretend for a long time". One dimension to the authenticity that influencers revealed was how they downplayed certain negative aspects of their personality on screen and highlighted the positive attributes only. Influencer Nada Fouda commented: "My personality on the screen is $85 \%$ my real personality. What appears on the camera is my real personality but there are some things which I hide". Online, through the profile, either the authentic self or selected aspects of the self can be represented (Manago, Graham, Greenfield, \& Salimkhan, 2008).

In terms of content, influencers stressed how they develop their own content and don't borrow anyone else's. This was a key practice to display authenticity. For example, Influencer Alaa Ghabour stated: "My content is basically that I share my lifestyle with youth simply to inspire them, to help them, I wanted us to encourage each other. It can be considered motivational or inspirational". Influencers Lamia AlBardici, Samar Ahmed, Hoda Rashad all shared their experiences in using beauty products. In this they were similar to beauty and lifestyle vlogger Bubzbeauty who aimed to convey an authentic message when talking about her experiences with different beauty products (García-Rapp, 2016). Linked to developing original content was the practice of avoiding specific topics deliberately: sex, politics and religion, which are all taboo topics in Egypt. In this they are in line with the tactic of conformity and compliance 
(Leary, 1996) in that they are conforming and complying with the conservative nature of the Egyptian society (Gadallah et al., 2017; Mensch, Ibrahim, Lee, \& El-Gibaly, 2003). Influencer Mohamed Abdalkader explained: "I focus more on social content with no religious dimension, so a Christian or a Muslim may watch it and be convinced totally that it is correct". Influencer Alaa Ghabour echoed this:

Yes, I share things any average person does such as if you are a Muslim you pray and if you are a Christian you go to the church but I don't talk about religion or topics related to it as I said not because of the sensitivity.

Religion was one of topics which was used by some influencers but in an indirect form, subtly giving a religious dimension to their content. In this they understand how appealing the use of religion is in luring in audiences especially from the youth.

The second practice influencers used was going live; by this they display authenticity through interacting frequently and candidly with their fans through live videos on YouTube and stories on Facebook and Instagram. This gives their fans a glimpse of the influencers without being staged or scripted. This is a practice typically used by celebrities on Twitter to create an intimate and authentic persona (Marwick \& Boyd, 2011). Berriman \& Thomson (2015) explain that vlogs document an unpolished and unedited reality of YouTubers' personae and lifestyles. Moreover, vlogging, to display authenticity, has been connected with types of realism that aim to show real and authentic everyday experiences (Christian, 2011). Influencers stressed the particular strength of Instagram in enabling them to go live with their audiences. Influencer Samar Ahmed explains: "I can talk in the story; I can have a discussion with you about the story, so that you get my point of view". Influencer Nader ElKomely echoed this: "Sometimes I do live videos so that I can read their comments and if anyone wants to tell me anything, it's better to communicate via the live videos on Instagram". Similarly, Jerslev (2016) found that vloggers display a sense of authentic self through their straight-to-camera communication. Trammell and Keshelashvili (2005) found that bloggers communicated directly with the audience and asked for their opinions.

The third practice influencers depended on was their use of photographs especially selfies on all social media platforms. In that they realise that selfies and self-photographs are important elements to construct authenticity (Lobinger \& Brantner, 2015). According to Audrezet et al. (2018), authenticity was observable within influencers' content through elements expressing creativity such as original pictures, text, and the occasional video. An important finding was that influencers, to display authenticity, focused on using photographs that came across as ordinary. To achieve this, they took photographs with very normal backdrops, avoiding for example expensive hotels and luxury locations, which could give their fans a different impression. Influencer Nader Ahmed explained: 
I am very natural on social media, so I don't post pictures of me in exotic locations, I post very basic photographs and stories. So, they feel I can do something like him, he is a normal person and has become very successful.

This representation of ordinariness helps influencers create a sense of authenticity and to be true to life (Banks, 2015; Hou, 2019)

The fourth and last practice, which some, not all influencers, used was deliberately maintaining a distance between them and their fans to create an aura of mystique around them. This was a practice they borrowed from celebrities who are well accustomed to this practice (Bielby \& Gamson, 1995; Fung, 2009). Influencer Nader Ahmed explained:

I make sure to keep the imaginary part in people's minds about me there, so I don't meet them so that they have this imagination around me ... Like celebrities if you see them daily the passion and curiosity will decrease.

This was important for the influencers to keep the "WOW factor", as they described, alive. Of course, having a fanbase of more than one million helped achieve this as time could be stated as the reason for not maintaining closeness with fans. That is why micro-influencers are perceived by marketing agencies as having more access and interaction with their fans (Bernazzani, 2019; Gottbrecht, 2016; Hatton, 2018; Langan, 2019).

\section{Concluding thoughts}

This study examined how Egyptian influencers build their online persona. They take on this task for themselves, given the lack of gatekeepers in social media. The importance of influencers stems from their audience which is composed largely of youth who represent an important group in society as they are considered agents of change (United Nations Development Programme, 2016). Influencers took to social media motivated by building their fanbases which meant more money for them ultimately. The start for most influencers was a random start then they started to develop themselves more when they found that they were well received. They used a number of practices and tactics to build their online persona aiming to perform authentically. They were in line with Goffman's dramaturgical approach (Goffman, 1959) and Leary's self-presentational tactics (Leary, 1996). Within their displays of authenticity, they used a number of practices: developing original content and avoiding taboo topics; using photographs and selfies; going 'live' with their audiences; and maintaining a distance between them and their audiences. This study demonstrated that approaches and concepts which have been developed in the West are applicable to different contexts, such as in this case, they are applicable to Egypt, a developing country. The limitation of this study, which was conducted in Egypt with Egyptian influencers and the interviews were conducted mainly in Arabic, was that the reader may miss some local nuances although every attempt was 
International Journal of Innovation, Creativity and Change. www.ijicc.net

Volume 14, Issue 11, 2020

taken to not only translate the interviews but to project an accurate meaning of every word. For future studies the recommendation is to study the impact of influencers on their audiences. 
International Journal of Innovation, Creativity and Change. www.ijicc.net

Volume 14, Issue 11, 2020

\section{REFERENCES}

Abidin, C. (2015). Communicative $\bullet$ intimacies: Influencers and Perceived Interconnectedness. Ada: A Journal of Gender, New Media, and Technology. https://doi.org/10.7264/N3MW2FFG

Abidin, C., \& Ots, M. (2015). The Influencer's dilemma: The shaping of new brand professions between credibility and commerce. AEJMC 2015, Annual Conference, "Media Branding Revised: Participative Audiences and Their Consequences for Media Branding, 1-12. San Francisco.

Aran-Ramspott, S., Fedele, M., \& Tarragó, A. (2018). Youtubers' social functions and their influence on pre-adolescence. Comuicar, 57(XXVI), 71-79.

Attia, A., Aziz, N., Friedman, B., \& Elhusseiny, M. (2011). Commentary: The impact of social networking tools on political change in Egypt's "Revolution 2.0." Electronic Commerce Research and Applications, 10(4), 369-374. https://doi.org/10.1016/j.elerap.2011.05.003

Audrezet, A., de Kerviler, G., \& Guidry Moulard, J. (2018). Authenticity under threat: When social media influencers need to go beyond self-presentation. Journal of Business Research. https://doi.org/10.1016/j.jbusres.2018.07.008

Ayish, M., \& Alnajjar, A. (2019). Arab millennial identity in cyberspace Arab Millennials' Articulation of Identity in Cyberspace: A study of three MENA YouTubers. Arab Media and Society, Winter/Spr(27), 26-40.

Banet-Weiser, S. (2012). AuthenticTM: The Politics of Ambivalence in a Brand Culture. New York and London: NYU Press.

Banks, M. (2015). True to life: Authenticity and the photographic image. In T. Fillitz \& J. Saris (Eds.), Debating Authenticity: Concepts of Modernity in Anthropological Perspective (pp. 160-171). New York, Oxford: Berghahn Books.

Bernazzani, S. (2019). Micro-Influencer Marketing: A Comprehensive Guide. Retrieved January 26, 2020, from HubSCheckedpot website: https://blog.hubspot.com/marketing/micro-influencer-marketing

Berriman, L., \& Thomson, R. (2015). Spectacles of intimacy? Mapping the moral landscape of teenage social media. Journal of Youth Studies, 18(5), 583-597. https://doi.org/10.1080/13676261.2014.992323

Berryman, R., \& Kavka, M. (2017). 'I Guess A Lot of People See Me as a Big Sister or a Friend': the role of intimacy in the celebrification of beauty vloggers. Journal of 
International Journal of Innovation, Creativity and Change. www.ijicc.net Volume 14, Issue 11, 2020

Gender Studies, 26(3), 307-320. https://doi.org/10.1080/09589236.2017.1288611

Beverland, M., Farrelly, F., \& Quester, P. (2010). Authentic subcultural membership: Antecedents and consequences of authenticating acts and authoritative performances. Psychology and Marketing, 27(7), 698-716. https://doi.org/10.1002/mar.20352

Bhuiyan, S. (2011). Social Media and Its Effectiveness in the Political Reform Movement in Egypt. Middle East Educator, 1(1). Retrieved from http://ro.uow.edu.au/cgi/viewcontent.cgi?article $=1002 \&$ context=meme

Bielby, D., \& Gamson, J. (1995). Claims to Fame: Celebrity in Contemporary America. Contemporary Sociology, 24(1), 117. https://doi.org/10.2307/2075149

Birnbaum, M. (2008). Taking Goffman on a tour of Facebook: College students and the presentation of self in a mediated environment [PhD Dissertation]. University of Arizona.

Bullingham, L., \& Vasconcelos, A. (2013). 'The presentation of self in the online world': Goffman and the study of online identities. Journal of Information Science, 39(1), 101112. https://doi.org/10.1177/0165551512470051

Burns, T. (1992). Erving Goffman. Routledge.

Chapple, C., \& Cownie, F. (2017). An Investigation into Viewers' Trust in and Response Towards Disclosed Paid-for-Endorsements by YouTube Lifestyle Vloggers. Journal of Promotional Communications, 5(2), 110-136.

Christian, A. (2011). Joe Swanberg, Intimacy, and the Digital Aesthetic. Cinema Journal, 50(4), 117-135. https://doi.org/10.1353/cj.2011.0049

Cocker, H., \& Cronin, J. (2017). Charismatic authority and the YouTuber. Marketing Theory, 17(4), 455-472. https://doi.org/10.1177/1470593117692022

Colliander, J., \& Dahlén, M. (2011). Following the Fashionable Friend: The Power of Social Media. Journal of Advertising Research, 51(1), 313-320. https://doi.org/10.2501/JAR$\underline{51-1-313-320}$

De Veirman, M., Cauberghe, V., \& Hudders, L. (2017). Marketing through Instagram influencers: the impact of number of followers and product divergence on brand attitude. International Journal of Advertising, 36(5), 798-828. https://doi.org/10.1080/02650487.2017.1348035

Dubai. (2018). Arab Media Outlook (2016-2018: Youth Content Digital Media (5th ed.). Dubai: Dubai Media City and Dubai Press Club. Retrieved from Dubai Media City and Dubai Press Club website: https://egypt.mom- 
International Journal of Innovation, Creativity and Change. www.ijicc.net

Volume 14, Issue 11, 2020

rsf.org/uploads/tx_lfrogmom/documents/7-1456_import.pdf

Ellcessor, E. (2012). Tweeting @feliciaday: Online Social Media, Convergence, and Subcultural Stardom. Cinema Journal, 51(2), 46-66. https://doi.org/10.1353/cj.2012.0010

Enli, G. (2015). Mediated Authenticity: How the Media Constructs Reality. New York: Peter Lang Publishing Inc.

Freberg, K., Graham, K., McGaughey, K., \& Freberg, L. (2011). Who are the social media influencers? A study of public perceptions of personality. Public Relations Review, 37(1), 90-92. https://doi.org/10.1016/j.pubrev.2010.11.001

Friedrichsen, M., \& Mühl-Benninghaus, W. (Eds.). (2013). Handbook of Social Media Management. Berlin, Heidelberg: Springer Berlin Heidelberg. https://doi.org/10.1007/978-3-642-28897-5

Fung, A. (2009). Faye and the Fandom of a Chinese Diva. Popular Communication, 7(4), 252266. https://doi.org/10.1080/15405700903177552

Gadallah, M., Roushdy, R., \& Sieverding, M. (2017). Young people's gender role attitudes over the transition to adulthood in Egypt (No. 1122). Giza: The Economic Research Forum (ERF). Retrieved from The Economic Research Forum (ERF) website: https://erf.org.eg/publications/young-peoples-gender-role-attitudes-over-thetransition-to-adulthood-in-egypt/

García-Rapp, F. (2016). The digital media phenomenon of YouTube beauty gurus: the case of Bubzbeauty. International Journal of Web Based Communities, 12(4), 360. https://doi.org/10.1504/IJWBC.2016.080810

Given, L. (Ed.). (2008). The SAGE Encyclopedia of Qualitative Research Methods Volumes 1\&2. Los Angeles: SAGE Publications.

Goffman, E. (1959). The Presentation of Self in Everyday Life. New York, NY: Doubleday.

Gottbrecht, L. (2016, October 18). The Three Types of Influencers All Marketers Should Know [Infographic]. Retrieved December 15, 2019, from Mavrck website: https://www.mavrck.co/the-three-types-of-influencers-all-marketers-should-knowinfographic/

Hatton, G. (2018, February 13). Micro influencers vs macro influencers. Retrieved January 26, 2020, from Social Media Today website: https://www.socialmediatoday.com/news/micro-influencers-vsmacroinfluencers/51689/

Herrera, L. (2012). Youth and Citizenship in the Digital Age: A View from Egypt. Harvard 
International Journal of Innovation, Creativity and Change. www.ijicc.net

Volume 14, Issue 11, 2020

Educational Review, 82(3),

$333-352$.

https://doi.org/10.17763/haer.82.3.88267r117u710300

Hou, M. (2019). Social media celebrity and the institutionalization of YouTube. Convergence: The International Journal of Research into New Media Technologies, 25(3), 534-553. https://doi.org/10.1177/1354856517750368

Hurley, Z. (2019). Imagined Affordances of Instagram and the Fantastical Authenticity of Female Gulf-Arab Social Media Influencers. Social Media + Society, 5(1), 205630511881924. https://doi.org/10.1177/2056305118819241

Jenkins, R. (2008). Social Identity (3rd ed.). Abingdon: Routledge.

Jerslev, A. (2016). In the time of the microcelebrity: Celebrification and the YouTuber Zoella. International Journal of Communication, (10), 5233-5251.

Jorge, A., Marôpo, L., \& Nunes, T. (2018). 'I am not being sponsored to say this': a teen youtuber and her audience negotiate branded content. Observatorio $\left(O B S^{*}\right)$, (Special issue on The co-option of audiences in the attention economy), 076-096. https://doi.org/10.15847/obsOBS0001382

Jung, D., Petersen, M., \& Sparre, S. (2014). Politics of Modern Muslim Subjectivities. New York: Palgrave Macmillan US. https://doi.org/10.1057/9781137380654

Khamis, S., \& Vaughn, K. (2011). Cyberactivism in the Egyptian revolution: How civic engagement and citizen journalism tilted the balance. Arab Media \& Society, (13). Retrieved from www.arabmediasociety.com/?article $=769$

Khamis, S., Gold, P., \& Vaughn, K. (2012). Beyond Egypt's "Facebook Revolution" and Syria's "YouTube Uprising:" Comparing Political Contexts, Actors and Communication Strategies. Arab Media \& Society, 15(Spring), 1-30. Retrieved from https://www.arabmediasociety.com/beyond-egypts-facebook-revolution-and-syriasyoutube-uprising-comparing-political-contexts-actors-and-communication-strategies/

Langan, H. (2019, October 29). Research Shows Micro-Influencers Drive Consumer Buying Behavior at Much Higher Rates Than Previously Thought. Retrieved February 17, 2020, from ExpertVoice website: expertvoice.com/new-research-shows-microinfluencers-drive-consumer-buying-behavior-much-higher-rates-previously-thought/

Leary, M. (1996). Social psychology series. Self-presentation: Impression management and interpersonal behavior. Westview: Boulder, CO.

Lee, J., \& Watkins, B. (2016). YouTube vloggers' influence on consumer luxury brand perceptions and intentions. Journal of Business Research, 69(12), 5753-5760. https://doi.org/10.1016/j.jbusres.2016.04.171 
International Journal of Innovation, Creativity and Change. www.ijicc.net Volume 14, Issue 11, 2020

Lobinger, K., \& Brantner, C. (2015). In the Eye of the Beholder: Subjective Views on the Authenticity of Selfies. International Journal of Communication, (9), 1848-1860.

Manago, A., Graham, M., Greenfield, P., \& Salimkhan, G. (2008). Self-presentation and gender on MySpace. Journal of Applied Developmental Psychology, 29(6), 446-458. https://doi.org/10.1016/j.appdev.2008.07.001

Marôpo, L., Jorge, A., \& Tomaz, R. (2020). "I felt like I was really talking to you!”: intimacy and trust among teen vloggers and followers in Portugal and Brazil. Journal of Children and Media, 14(1), 22-37. https://doi.org/10.1080/17482798.2019.1699589

Martínez, C., \& Olsson, T. (2019). Making sense of YouTubers: how Swedish children construct and negotiate the YouTuber Misslisibell as a girl celebrity. Journal of Children and Media, 13(1), 36-52. https://doi.org/10.1080/17482798.2018.1517656

Marwick, A. (2005). I'm More Than Just a Friendster Profile: Identity, Authenticity, and Power in Social Networking Services. In Association for Internet Researchers 6.0 (Vol. 6).

Marwick, A., \& Boyd, D. (2011). To See and Be Seen: Celebrity Practice on Twitter. Convergence: The International Journal of Research into New Media Technologies, 17(2), 139-158. https://doi.org/10.1177/1354856510394539

Mensch, B., Ibrahim, B., Lee, S., \& El-Gibaly, O. (2003). Gender-role Attitudes among Egyptian Adolescents. Studies in Family Planning, 34(1), 8-18. https://doi.org/10.1111/j.1728-4465.2003.00008.x

Meyers, E. (2009). “Can You Handle My Truth?”: Authenticity and the Celebrity Star Image. The Journal of Popular Culture, 42(5), 890-907. https://doi.org/10.1111/j.1540$\underline{5931.2009 .00713 . \mathrm{x}}$

Morozov, E. (2011). The Net Delusion the Dark Side of Internet Freedom. New York: PublicAffairs.

Moulard, J., Garrity, C., \& Rice, D. (2015). What Makes a Human Brand Authentic? Identifying the Antecedents of Celebrity Authenticity. Psychology \& Marketing, 32(2), 173-186. https://doi.org/10.1002/mar.20771

Moulard, J., Raggio, R., \& Folse, J. (2016). Brand Authenticity: Testing the Antecedents and Outcomes of Brand Management's Passion for its Products. Psychology \& Marketing, 33(6), 421-436. https://doi.org/10.1002/mar.20888

Moulard, J., Rice, D., Garrity, C., \& Mangus, S. (2014). Artist Authenticity: How Artists' Passion and Commitment Shape Consumers' Perceptions and Behavioral Intentions across Genders. Psychology \& Marketing, 31(8), 576-590. https://doi.org/10.1002/mar.20719 
International Journal of Innovation, Creativity and Change. www.ijicc.net

Volume 14, Issue 11, 2020

Nesvadba, N. (2017). The presentation of self in the digital world: Goffman and the study of Women's self-portrayal on Instagram through selfies [Master's Thesis]. Loughborough University.

Olorunnisola, A., \& Martin, B. (2013). Influences of media on social movements: Problematizing hyperbolic inferences about impacts. Telematics and Informatics, 30(3), 275-288. https://doi.org/10.1016/j.tele.2012.02.005

Pérez-Torres, V., Pastor-Ruiz, Y., \& Abarrou-Ben-Boubaker, S. (2018). YouTuber videos and the construction of adolescent identity. Comunicar, 26(55), 61-70. https://doi.org/10.3916/C55-2018-06

PressRoom. (2015, January 14). Young Egyptians "Breaking the Internet."

Raun, T. (2018). Capitalizing intimacy. Convergence: The International Journal of Research into New Media Technologies, 24(1), 99-113. https://doi.org/10.1177/1354856517736983

Roushdy, R., \& Sieverding, M. (Eds.). (2015). Panel survey of young people in Egypt 2014: Generating evidence for policy, programs, and research. Cairo: Population Council.

Ruiz-Gomez, A. (2019). Digital Fame and Fortune in the age of Social Media: A Classification of social media influencers. ADResearch ESIC International Journal of Communication Research, 19(19), 08-29. https://doi.org/10.7263/adresic-019-01

Sabbagh, K., Mourad, M., Kabbara, W., Shehadi, R., \& Samman, H. (2012). Understanding the Arab Digital Generation.

Senft, T. (2008). Camgirls: Celebrity \& Community in the Age of Social Networks. New York: Peter Lang.

Serpa, S., \& Ferreira, C. M. (2018). Goffman's Backstage Revisited: Conceptual Relevance in Contemporary Social Interactions. International Journal of Social Science Studies, 6(10), 74. https://doi.org/10.11114/ijsss.v6i10.3659

Smith, G. (2006). Erving Goffman. Routledge.

Therborn, G. (2004). Between Sex and Power. London: Routledge. https://doi.org/10.4324/9780203643297

Trammell, K., \& Keshelashvili, A. (2005). Examining the New Influencers: A SelfPresentation Study of A-List Blogs. Journalism \& Mass Communication Quarterly, 82(4), 968-982. https://doi.org/10.1177/107769900508200413

UNFPA Egypt. (2020). Young people. Retrieved April 7, 2020, from 
International Journal of Innovation, Creativity and Change. www.ijicc.net

Volume 14, Issue 11, 2020

https://egypt.unfpa.org/en/topics/young-people-14

United Nations. (2018). World Youth Report: Youth and the 2030 Agenda for Sustainable Development World. New York: United Nations. Retrieved from United Nations website:

https://www.un.org/development/desa/youth/wpcontent/uploads/sites/21/2018/12/WorldYouthReport-2030Agenda.pdf

United Nations Development Programme. (2016). Arab Human Development Report 2016 Youth and the prospects for human development in a changing reality. New York. Retrieved from http://www.arabstates.undp.org/content/dam/rbas/report/AHDR Reports/AHDR 2016/AHDR Final 2016/AHDR2016En.pdf

Uzunoğlu, E., \& Misci Kip, S. (2014). Brand communication through digital influencers: Leveraging blogger engagement. International Journal of Information Management, 34(5), 592-602. https://doi.org/10.1016/j.ijinfomgt.2014.04.007

Westenberg, W. (2016). The influence of YouTubers on teenagers A descriptive research about the role YouTubers play [Master's Thesis]. University of Twente.

YouTube. (2020). Trending on YouTube. Retrieved March 20, 2020, from https://support.google.com/youtube/answer/7239739?hl=en 